\title{
Prevalence of Methicillin-resistant Staphylococcus aureus in the Surgical Wards of the Port-of-Spain General Hospital, Trinidad and Tobago
}

\author{
MJ Ramdass, S Balliram, A Cadan, N Bhaggan, B Mohammed, R Singh, J Maharaj, A Boodram
}

\begin{abstract}
Objective: Methicillin-resistant Staphylococcus aureus (MRSA) is associated with soft tissue infections in surgical patients. In severe cases, it may result in pneumonia, septicaemia and osteomyelitis. Limited data are available with regard to its prevalence and associations in the Caribbean. This study aimed to assess the prevalence of MRSA in patients hospitalized in the surgical wards of the Port-of-Spain General Hospital (POSGH), Trinidad and Tobago, and determine associated risk factors.

Methods: Over the period of April 1 to August 1, 2013, all patients from the surgical wards of the POSGH who had had wound swabs taken were identified. Demographic data included duration of hospital stay, surgical and medical history, antibiotic use and type of wound swab. Microbiological reports were then retrieved and analyses done.

Results: A total of 153 patients had wound swabs taken. There were 38 patients (24\%) infected with Staphylococcus aureus, with 15 (39.5\%) growing MRSA. Increased susceptibility to MRSA was associated with age, gender, ethnicity, duration of hospital stay, co-morbidities, previous antibiotic use, previous surgery and the type of wound $(\mathrm{p}<0.05)$.

Conclusion: The prevalence of MRSA in the surgical wards of the POSGH was 39.5\% of Staphylococcus aureus isolates. Risk factors included the age range of 60-69 years, patients with co-morbidities, hospital stays of longer than one week, previous surgery and prior use of antibiotics. We recommend more awareness of this problem in the practice of Caribbean medicine to improve infection rates.
\end{abstract}

Keywords: Methicillin-resistant Staphylococcus aureus, surgical wards, West Indies

\section{Prevalencia del estafilococo dorado resistente a la meticilina en las salas quirúrgicas del Hospital General de Puerto España, Trinidad y Tobago}

MJ Ramdass, S Balliram, A Cadan, N Bhaggan, B Mohammed, R Singh, J Maharaj, A Boodram

\begin{abstract}
RESUMEN
Objetivo: El estafilococo dorado resistente a la meticilina (EDRM) se asocia con infecciones de tejidos blandos en pacientes quirúrgicos. En casos severos, puede dar lugar a pulmonía, septicemia y osteomielitis. Los datos disponibles con respecto a su prevalencia y asociaciones en el Caribe son limitados. Este estudio persigue evaluar la prevalencia de EDRM en pacientes hospitalizados en las salas quirúrgicas del Hospital General de Puerto de España (POSGH, siglas en inglés) en Trinidad y Tobago, y determinar los factores de riesgo asociados.
\end{abstract}

From: Department of Clinical Surgical Sciences, The University of the West Indies, St Augustine, Trinidad and Tobago, West Indies, and Port-of-Spain General Hospital, Trinidad and Tobago, West Indies.
Correspondence: Mr MJ Ramdass, Port-of-Spain General Hospital, 61 Charlotte Street, Port-of-Spain, Trinidad and Tobago, West Indies. Email: jimmyramdass@gmail.com 
Métodos: Durante el período del 1 de abril al 1 de agosto de 2013, fueron identificados todos los pacientes de las salas quirúrgicas del Hospital POSGH a quienes se les habia practicado frotis de las heridas. Los datos demográficos incluyeron la duración de la estadía hospitalaria, las historias clínicas y quirúrgicas, el uso de antibióticos, y el tipo de frotis de la herida. Luego se obtuvieron los informes microbiológicos y se realizaron los análisis.

Resultados: A un total de 153 pacientes se le tomaron frotis de heridas. Hubo 38 pacientes (24\%) infectados con estafilococos dorados, de los cuales 15 (3.5\%) presentaban EDRM creciente. El aumento de la susceptibilidad a EDRM se asoció con la edad, el género, la etnicidad, la duración de la estadía hospitalaria, las co-morbilidades, el uso previo de antibióticos, las cirugías previas, y el tipo de herida $(\mathrm{p}<0.05)$.

Conclusión: La prevalencia de EDRM en las salas quirúrgicas del Hospital POSGH fue 39.5\% de aislados de estafilococos dorados. Los factores de riesgo incluyeron un rango de edad de 60-69 años, pacientes con co-morbilidades, estancia hospitalaria de más de una semana, cirugía previa, y uso previo de antibióticos. Recomendamos tomar más conciencia de este problema en la práctica médica en el Caribe a fin de mejorar las tasas de infección.

Palabras clave: EDRM, salas de cirugía, Caribe

West Indian Med J 2018; 67 (1): 58

\section{INTRODUCTION}

In Trinidad and Tobago, data with respect to the prevalence of methicillin-resistant Staphylococcus aureus (MRSA) are limited. Statistical data suggest that as many as 19000 people per year die from MRSA in the United States of America $(1,2)$. This report presents the prevalence and risk factors of MRSA in patients hospitalized in the surgical wards of the Port-of-Spain General Hospital (POSGH), Trinidad and Tobago.

\section{SUBJECTS AND METHODS}

Ethical approval was obtained from The University of the West Indies and the North West Regional Health Authority to collect data. There were no ethical issues. Data were collected prospectively from April 1, 2013 for a four-month period on surgical patients who had wound swabs. These included age, gender, ethnicity, address, occupation, duration of hospital stay, medical history, antibiotic history, type of wound, surgical history, previous hospitalization and presence/absence of MRSA. Type of wound consisted of surgical wounds from previous surgery, diabetic foot, ulcerative wounds, abscess, laceration, septic feet, and 'other' (which included gunshot wounds, dog bites and insect bites). Analysis was done using IBM SPSS statistical programme, version 20. The Chi-square and independent sample t-test were applied.

\section{RESULTS}

Over the four-month period, there were 112 male (73\%) and 41 female (27\%) MRSA-positive cases, with the peak age range being 60-69 years (Figure). Of the 153 cases, there were 38 patients with Staphylococcus aureus (S aureus), of which 15 were MRSA-positive, giving an overall prevalence rate of $9.8 \%$ and a MRSA prevalence rate of $39.4 \%$ of all $S$ aureus isolates. With regard to ethnicity, $80 \%$ of the MRSA-positive patients were of Afro-Caribbean descent and 20\% were of East Indian descent.

Risk factors, mainly longer duration of hospital stay, increased the chance of MRSA positivity: 11 (73\%) out of the 15 MRSA-positive patients stayed at POSGH for a period of above one week but below three months. Also, patients who were previously hospitalized (9; $60 \%)$ or had previous surgery $(10 ; 67 \%)$ proved to be at an increased risk.

With respect to the use of antibiotics, 14 of the 15 MRSA-positive patients (93\%) had previously used antibiotics, with 13 using beta-lactam penicillins prior to admission. Fourteen patients had co-morbidities, with diabetes mellitus and hypertension being most common. Statistical significance was achieved using the independent sample $t$-test for the type of wound, with 6 out of 15 MRSA-positive patients having a surgical wound (previous surgery) as opposed to a diabetic foot, abscess, laceration or ulcer (Table). 


\section{DISCUSSION}

Methicillin-resistant Staphylococcus aureus has become a widespread cause of hospital-acquired infection globally with life-threatening complications (1). This continues to grow and contributes significantly to the morbidity and mortality of hospital in-patients $(2,3)$.

In Trinidad and Tobago, several studies have been conducted on the prevalence of methicillin resistance among $S$ aureus isolates at primary care facilities (3-5). The findings suggest a sustained increase in the number of reported MRSA cases within the hospital environment. The prevalence rate in the early $1990 \mathrm{~s}$ was $0.7 \%$, rising to $12.5 \%$ by the year 1999 (3). Between 1999 and $2004,20.8 \%$ of $S$ aureus isolates analysed from health facilities across the country were methicillin-resistant (4). It is clear that strategies implemented in attempts to curb the spread of MRSA have proved futile. The deteriorating statistical evidence is consistent with regional and international trends $(3,4)$.

The increasing prevalence of MRSA in Trinidad and Tobago has been attributed to a range of issues, including hospital accommodation constraints, shortage of personnel and a lack of adequate infection control measures and implementation of recommendations. An interesting development is the increasing emergence of non-nosocomial infections. Within a six-year period (1999-2004), the amount of MRSA cases in the community increased from $4.1 \%$ to $8.1 \%(3,4)$.

This study was undertaken to estimate the prevalence of MRSA in the surgical wards of the POSGH, which is

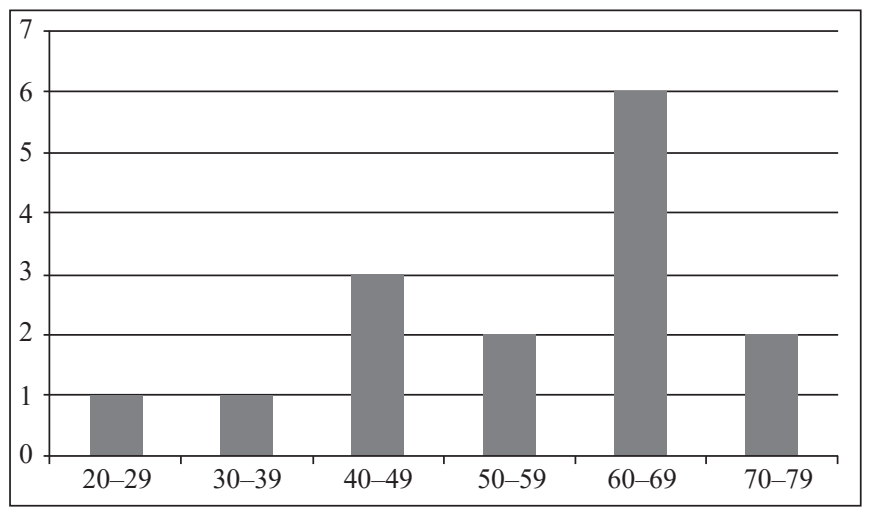

Figure: Age range (years) and MRSA presence. one of the main referral centres in the country. The overall MRSA prevalence rate was $9.8 \%$ with a $39.5 \%$ rate for $S$ aureus isolates. This value of methicillin resistance among $S$ aureus isolates is notably higher than those found in previous studies: $9.8 \%$ in 1999 (5), 12.8\% in 2000-01 (3) and 20.5\% in 2004 (4).

Results of this research maintained the trend of increasing MRSA prevalence seen between 2000 and 2004. However, the notably higher prevalence derived could have been attributed to a bias in sample size. In 2000 and 2004, the $S$ aureus isolates were 1912 and 2430 , respectively, whereas this study was limited to a sample of 38. Also, this study was restricted to the POSGH, whereas the study of 2004 had a wider sample of patients from hospitals, health centres, outpatient clinics and general practitioners.

Nevertheless, the data herein presented show an alarming MRSA rate at one of the main tertiary centres in Trinidad and Tobago. It is hoped that these data will assist healthcare providers with the prevalence rate of MRSA and recommend appropriate measures to reduce transmission.

\section{ACKNOWLEDGEMENTS}

The authors would like to acknowledge the ethics committees of the North West Regional Health Authority and of The University of the West Indies for their assistance in this project.

\section{REFERENCES}

1. Barber M. Methicillin-resistant staphylococci. J Clin Path 1961; 14: 385-93.

2. Centers for Disease Control and Prevention, United States of America. Staphylococcus aureus with reduced susceptibility to vancomycin United States, 1997. Available from: www.cdc.gov/mmwr/preview/ mmwrhtml/00049042.htm. MMWR Morb Mortal Wkly Rep 1997; 46: 813-5.

3. Akpaka PE, Kissoon S, Swanston WH, Monteil M. Prevalence and antimicrobial susceptibility pattern of methicillin resistant Staphylococcus aureus isolates from Trinidad \& Tobago. Ann Clin Microbiol Antimicrob 2006; 5: 16.

4. Orrett FA, Land M. Methicillin-resistant Staphylococcus aureus prevalence: current susceptibility patterns in Trinidad. BMC Infect Dis 2006; 6: 83 .

5. Orrett FA. Methicillin resistance among Trinidadian isolates of community and hospital strains of Staphylococcus aureus and their patterns of resistance to non-beta-lactam antibiotics. Jpn J Infect Dis 1999; 52: $238-41$.

Table: The association of type of wound, co-morbidities and duration of hospital stay with MRSA presence

\begin{tabular}{llllll}
\hline Type of wound and MRSA presence & Abscess $=2$ & Diabetic foot $=3$ & Laceration $=1$ & Surgical wound $=6$ & Ulcer $=3$ \\
Co-morbidities and MRSA presence & Diabetes $=7$ & Hypertension $=8$ & Malignancy $=1$ & Cardiovascular disease $=3$ & Respiratory disease $=1$ \\
$\begin{array}{l}\text { Duration of hospital stay and MRSA } \\
\text { presence }\end{array}$ & $<1$ week $=4$ & $>1$ week, $<1$ month $=9$ & $1-3$ months $=2$ & & \\
\hline
\end{tabular}

